\title{
Natalia Wałęsa
}

Wroclaw University of Economics

nwalesa@wp.pl

\section{THE IMPORTANCE OF FINANCIAL INVESTMENT USING THE EXAMPLE OF THE FINANCIAL INSTRUMENT OF MUNICIPAL BONDS OF THE MUNICIPALITY OF OSTRÓW WIELKOPOLSKI}

\section{ZNACZENIE INWESTYCJI FINANSOWYCH NA PRZYKLADZIE INSTRUMENTU FINANSOWEGO OBLIGACJI KOMUNALNYCH W OSTROWIE WIELKOPOLSKIM}

DOI: $10.15611 /$ ekt.2015.1.06

Summary: The purpose of this publication is to present the importance of financial investment using the example of the financial instrument of municipal bonds of the Municipality of Ostrów Wielkopolski. The budget support offered by the bond issue is not comparable with the possibilities of what can be achieved without issuing securities. After many years, bonds have become one of the main subjects in the capital market. Since the 1990s the issue of bonds has been growing in many municipalities including Łódź, Ostrów Wielkopolski, Kraków, Warszawa and many, many others. Unfortunately, not all of these municipalities are so eager to realise their intentions, and thus the fact is that the development is carried out in the longer term. The subject of bonds is not an easy subject, good companies operating it today have a lot of work with it and do not want to physically engage in this difficult topic. Any intentional investment and revenue in the budgets of local governments rely on financial instruments, the securities of which are municipal bonds.

Keywords: investment, financial investment, financial instrument, municipal bonds.

Streszczenie: Celem niniejszej publikacji jest przedstawienie znaczenia inwestycji finansowej na przykładzie instrumentu finansowego obligacji komunalnych w Ostrowie Wielkopolskim. Oferowane wsparcie budżetowe w postaci emisji obligacji daje możliwości nieporównywalnie większe niż te, które istnieją bez emisji papierów wartościowych. Po wielu latach obligacje stały się jednym z głównych instrumentów na rynku kapitałowym. Od lat 90. emisja obligacji rosła w wielu gminach (Łódź, Ostrów Wielkopolski, Kraków, Warszawa i wielu, wielu innych). Niestety, nie wszystkie te gminy chętnie realizują swoje plany, a więc ich rozwój odbywa się wolniej. Wszelkie zamierzone inwestycje i przychody do budżetów samorządów opierają się na instrumentach finansowych, papierach wartościowych, którymi są obligacje komunalne.

Słowa kluczowe: inwestycja, inwestycja finansowa, instrument finansowy, obligacje komunalne. 


\section{Introduction}

Banks began to create special departments and started a few years ago to deal with the subject of bonds. They treat it as an emanation of a simplified credit - a bank loan. At the end of the bond is a security that can in some cases replace stocks or shares. Most of the people who addressed the issue of debenture come from the company departments, offices or brokers. From the beginning, it was noticed how big the loopholes were in the Act of June 29, 1995 on bonds, which gradually was transformed allowing for the use of the finer acts, and thus, the issue of bonds. It was an important fact that in the case of municipal bonds, for example, the inadequacy of regulatory bodies such as the RIO - Regional Audit Office was very worrying. However, to release the bonds the Regional Accounting Chamber must be informed of the intention to issue bonds. In all countries there are markets in which financial instruments are traded. They are called financial markets, which allows entities holding free cash for its disclosure to the notified on demand, and in return achieve certain future benefits. The capital market is understood as part of the financial market. Transactions that are being made include those financial instruments whose repayment term is longer than one year. Among these instruments securities occupy a significant place, as documents which provide for the owner of certain property rights such as the right to receive interest. They make their commercial transactions take place on the securities market. The securities market allows a choice to invest in a number of different instruments.

There are many securities we can choose to invest in - securities such as stocks, bonds (treasury, municipal, corporate, banking), and treasury bills. The price of these instruments depends on various factors such as currency or economic indicators. Investing in the stock market brings a wide range of decision making. The issuance of bonds, trading and redemption is primarily based on existing laws which should be studied before any decisions are made on that issue. In the library a reader can find a lot of interesting literature that is dedicated not only to the above-mentioned issue, but also to the further development, the next steps and ways of acquiring securities. Valuable sources are also websites, social networks and e-books providing answers to many questions directed to financial advisors as well as banks. Reading this work, the reader should remember that bond market is still in the process of formation. Every day, every month brings a new settlement, and thus, new directions, new comparisons and experience.

\section{The Financial Investment. What is it?}

In the literature there are several terms for the word "investment". Investing is one of the basic human activities in the field of economics. According to information

\footnotetext{
${ }^{1}$ The explanation of this concept can be found in many books, for example: [Jajuga, Jajuga 2007; Marcinek 2006; Różański 2006; Jajuga, Jajuga 2004; Trocki, Grucza, Ogonek 2003; Dziworski,
} 
included in professional texts there are four main features of the definition, which are: the risk (always appears with investment), benefits (very often expected by investors), timing (the time is very important when the investor want to achieve an income) and expenditure (which always appears with the definition of investment).

The basic types of investment are tangible investments and intangible (financial) investments. In the former, the main subject is concentrated on the material. The latter focuses on objects which are non-material representing only monetary value). Most people know there are many possibilities of investment. People take risk and invest, for example in real estate, gold or currencies. The financial instrument is the basic concept of financial investment ${ }^{2}$.

\section{The Concept of Municipal Bonds}

On the basis of the Act of June 29, 1995 on bonds No. 83, item 420 the definition of a bond can be found in many sources ${ }^{3}$.

The author of the publication wants to rely on the knowledge of professionals and shows that bonds may be issued by: businesses with legal identity and limited joint-stock partnership; municipalities, counties, the state, and also the related units and the capital city of Warsaw; other legal parties, authorized to issue bonds under other laws; financial institutions which are member of the Republic of Poland and the National Bank of Poland or at least one of the countries belonging to the Organization for Economic Cooperation and Development or the central bank of that country, or the institutions with which the Republic of Poland signed agreements governing the activities of such institutions in the Polish Republic and with the appropriate provisions for the issuance of bonds. These entities are referred to as bond issuers ${ }^{4}$.

Bonds differ mainly in the level of credit risk arising from the possibility of default by the issuer of the bonds. It is possible to distinguish low-risk bonds (sometimes it is assumed that bonds are risk-free, which is a simplification) and high-risk corporate bonds. In the debate the term "bond" is widely understood and rightly includes all the capital market instruments for which there may be trading on the secondary market. Sometimes these instruments are known under different names. A typical example is a mortgage bond [Jajuga, Jajuga 2007, p. 29]. Providing the total bond is a pledge or mortgage guarantee which are guaranteed by the National Bank of Poland. Partially covered bonds are those that are either not fully secured, the above-mentioned types of collateral, or protected in some other way. The issuer of unsecured bonds may be an entity that prepared the financial statements for three consecutive financial years

\footnotetext{
Dziworska 1993; Gajęcki, Brochocka 1997; Kamerschen, McKenzie, Nardinelli 1991; Merkle 1980; Hirschleifer 1965].

${ }^{2}$ Information can be found in: [Czechowska 2010; Jajuga, Jajuga 2004; Electronic Sources 4, p. 7].

${ }^{3}$ Act of June 29, 1995 on bonds No. 83, item 420 [Jajuga, Jajuga 2004; Electronic Sources 2, p. 5].

${ }^{4}$ Ibidem.
} 
and the value of its equity and the equity itself is at least five times the minimum capital laid down by the Commercial Code [Czapla 1996, p. 41].

Municipal bonds are a particularly attractive financial instrument. Attractive to investors (because the issuer is particularly trustworthy, and in addition the interest on them shall be exempt from tax) and valuable for the whole of society and the economy (as it is used to raise capital for investments such as socially important water supply and roads). The popularity of European Union funds and the experience in obtaining them overshadowed municipal bonds. Municipal bonds are generally the safest financial instrument, which results from the nature of the issuer - the local government. Their profitability is higher than treasury bonds. Obligations under the bonds and the interest thereon will be certainly paid unless the same local government unit is closed down and that is not likely. Local government has a permanent source of income - taxes from the population, subsidies and grants, and the income of issued bonds was used to build some facility (e.g. a sewage treatment plant) [Electronic Sources 3].

\section{The sources of financing public investment}

Local government units are often faced with the challenge of how to manage effectively the financing of development in their area. Any opportunities and problems are different, depending on the local government - financial and policy instruments' designation: the common good of all citizens. Local self-government, in order to create conditions for improving the quality of life, should be part of the public funds that are at its disposal to spend on capital expenditure [MISTiA 2004, p. 1, 8]. Investment budget units perform alone or jointly with another operator. The effect of the finished work can be an investment in a unit or can be transferred to a budgetary co-investor. It affects the keeping of records for the respective accounts. By fixed assets under construction (investment) included in tangible fixed assets during their construction, we mean installation or improvement of an existing asset.

Whenever budget entities talk about investment this means, according to the Act of September 29, 1994 on Accounting, plant and equipment under construction. The sources of financing investments in the budget are: budget, funds from the sum of the principal and income of their own units [Electronic Sources 1]. Meeting the challenges of investment means that the city should have appropriate capital, own or external, such as credits, loans, issuance of bonds, and measures such as nonrepayable grants from the European Union. Given the fact that many governments are now under budgetary pressure, the role of the private sector in infrastructure financing is becoming more important than ever before. The scale of the investment needed clearly shows that the provision of an adequate budget funding level is unlikely, and certainly does not meet all the challenges of investment. Therefore there is a strong need for local governments to cooperate with the private sector, and use the capital market as a source of funding for urban projects [Electronic Sources 6]. 
In the case of meeting the challenges of investment by alternative methods of financing - where the government shares the risk with the private partner - the model must be adjusted to the conditions of the individual project, but also for the government to be committed to this particular investment on infrastructure. Investments have to be made to a public entity to pursue its commitment to the residents and provide public services [Electronic Sources 6].

According to financial actions, the author wants to present the alternative methods of financing, funding that can be used in the long-term planning of urban infrastructure development:

a) Re-use of public capital - the public capital commitment is to contribute to their own capital, mostly in the form of land for future investment or transfer of a non-repayable grant that does not generate a refund;

b) Public-Private Partnerships (PPP) on the basis of payment for availability the most classic model; the private sector designs, builds and maintains the finances and management of the infrastructure in return for the fees for the availability of the object after completion of the service;

c) Guarantees from the city of a minimum income for a specified period available only during the start of the project, when revenues are less certain, but only guarantees debt service rather than a return on invested capital. This approach allows to obtain economic benefits in the form of infrastructure which local governments cannot afford;

d) Infrastructure Bonds an instrument of a similar nature was known before the financial crisis, but now it is unlikely that the previous form will be brought back to the market;

e) Funding hybrid/mixed - the project is a combination of the structure of a hybrid public-private partnership with European Union funds in order to finance a part of the infrastructure;

f) Privatization of municipal companies through the stock exchange - Initial Public Offering is not currently used by the Polish community as a source of funding, but may be attractive because it is not the only way to obtain funding, but provides long-term access to the capital market shares;

g) Funding support through optimization - by increasing the available resources it is possible to own for governments as a result of the implementation of precisely planned austerity programs. This solution has been used successfully for years in Poland in the private sector, but also in the local government sector in Western Europe (such as the United Kingdom and Germany);

h) "Investment costs (assets under construction) include the value of the purchase price of used materials, the value of foreign services and their benefits, as well as non-deductible tax on goods and services for the investment, notary fees and any court fees, charged for the duration of the investment from foreign exchange differences taken from commitments by the investor and any extraordinary gains and losses related to the investment $[\ldots]$ ". 
i) Financing from the budget - the budgetary body receives budget for investments in accordance with the plan of expenditure from a higher level [Electronic Sources 6].

\section{The Municipal Bonds of Ostrów Wielkopolski - financial investments}

The issue of municipal bonds may be set to be either public or private. This means that the proposed acquisition or transfer of rights is not done via the media and is addressed to fewer than 300 identified persons [Electronic Sources 6]. Now, it has changed to 100 identified persons. "In the public one there are [...] bonds of Ostrów Wielkopolski. Getting them to the public was, however, at a later date, effected after the sale of bonds in the private placement" [Ostrowski, Stępniewski, Śliwiński 2005, p. 215]. Ostrów bonds are publicly traded.

Referring to bonds of the Municipality of Ostrów Wielkopolski, the author wants to present the explanation of the concept, as well as a brief history of the issuance of bonds. The bonds are the primary instrument of the capital market. In accordance with Polish law, it is possible to use the word "bond" to apply to short-term (issued for a period of less than one year) instruments issued by a company and by local government units. On the capital market there are instruments that from the point of view of their characteristics are bonds, but due to legal regulations or certain practices are applied in relation to their other name, a typical example is the mortgage bond. On 14th December 2010, Jarosław Urbaniak assumed the duties of the President of the City of Ostrów Wielkopolski. He has become a part of the so-called "Ostrowski management model", which was regarded as a model for other cities and towns. Ostrów Wielkopolski was the first in the country to issue municipal bonds, which in 2000 were recognized as the best on the market. Also, on an unprecedented scale, a procedure was to transform the Polish budgetary establishments into seven commercial companies and combine them into the Holdikom SA capital group. A number of investments were made: a new secondary school ('gimnazjum'), gyms at schools, modern sewage treatment plant, miles of sewers, the renovation of several streets and the Town Hall was restored [Electronic Sources 5]. It is worth saying that according to the classification from the perspective of the issuer, there are four basic types of bonds: treasury bonds, municipal bonds, corporate bonds, bonds of banks (these are less used than the others) [Jajuga, Jajuga 2007, p. 29]. All of them have been described before. Figure 1 below, shows all the bond issues and their value in Polish currency, which have been issued by the Municipality of Ostrów Wielkopolski since 1999 up to the current Mayor of the City Mr. Jarosław Urbaniak.

According to the above information, the author wants to concentrate on investing in municipal bonds. Doing the research and focusing on the issuing of securities, it can be said that in the first year of issuance the government issued 200000 bonds which were worth 100 PLN each. In the second year (2000), they made a smaller 

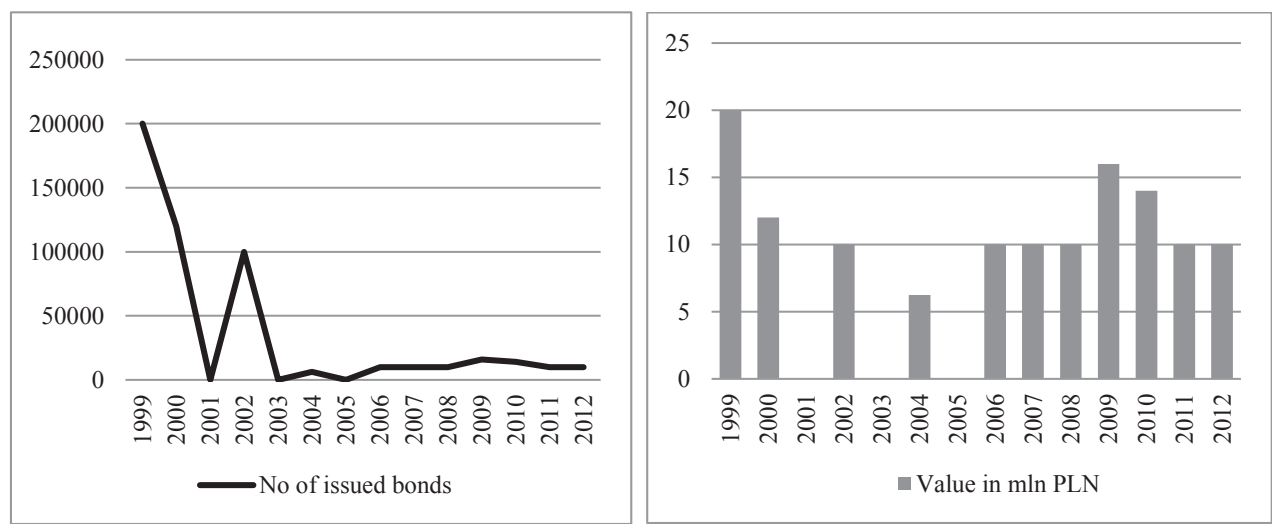

Fig. 1. Number of issued bonds and its equivalent in mln PLN

Source: own elaboration.

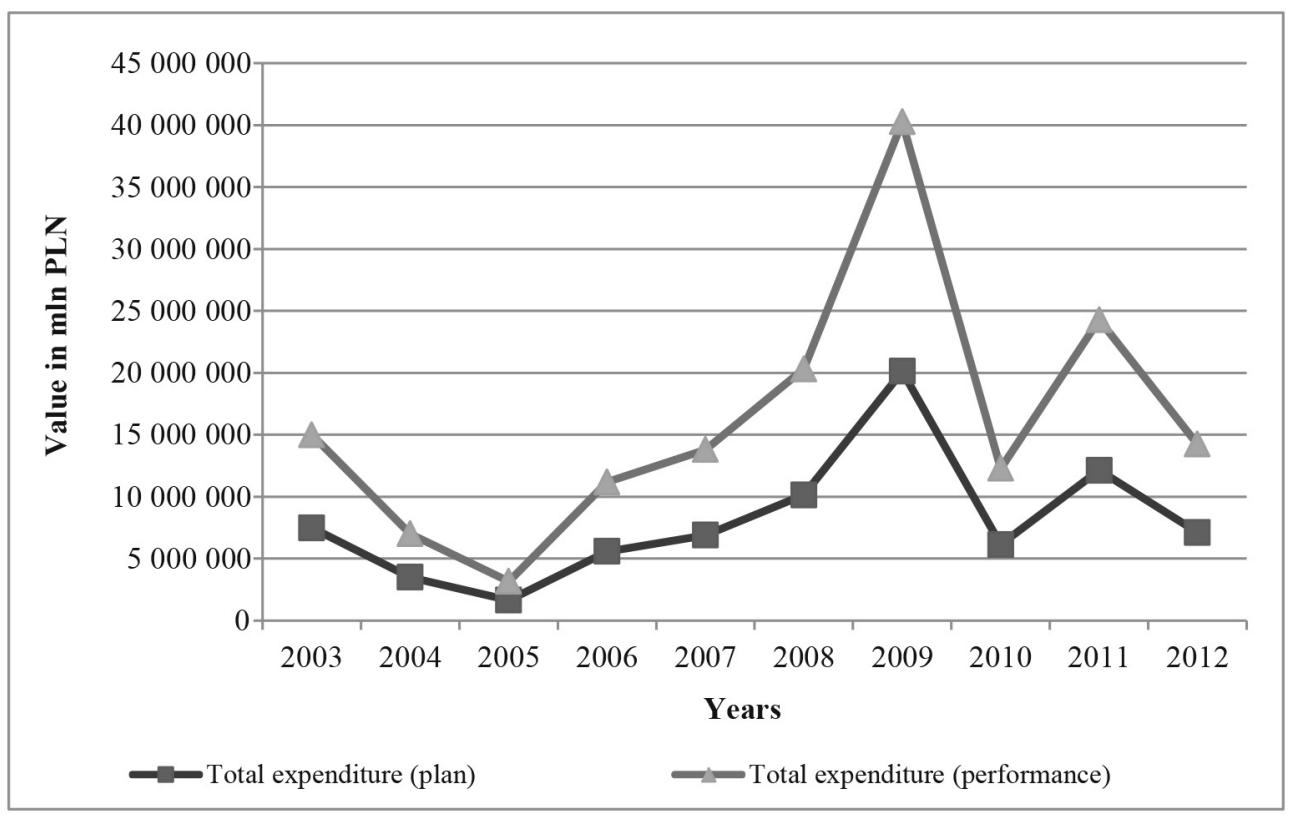

Fig. 2. The analysis of the implementation plan to the implementation performance of the expenditure of securities 2003-2012

Source: own elaboration.

issuance because of the lower demand and revenue, and in 2001 bonds were not issued as the government wanted to check how it would work during that time. In 2002 the Municipality of Ostrów Wielkopolski decided to make an issue of 100000 of 
bonds the value of which was $10 \mathrm{mln}$ PLN. A year after again no issue was made, just to research more how the demand and revenue would shape up. The same situation happened in 2003, 2004 and 2005, respectively with no issuance, but then issuing 6250 bonds of the value of 1000 PLN each, and in 2005 again stopped the issuance. From 2006 until 2012 the government issued bonds numbering 10000 , except for 2009 and 2010, when the number of issues was 16000 and 14000 respectively. Since that year (2006), all of the bonds have been valued at 1000 PLN each. Everything connected to issuance has been included in the presented graphs (Fig. 2).

The author would also like to show the importance of the issuance of bonds and its effect on the implementation plan to the implementation performance of the expenditure of securities from 2003 to 2012. In Graph 2 the author shows the total expenditure - performance to total expenditure - plan. According to this information, the reader can see in the chart all the expenditure analyzed by the author taken from the sources such as a financial statement of the Ostrów Wielkopolski Municipality. All data is included in the file mentioned before and anyone can check what the money was used for and how municipal bonds fared.

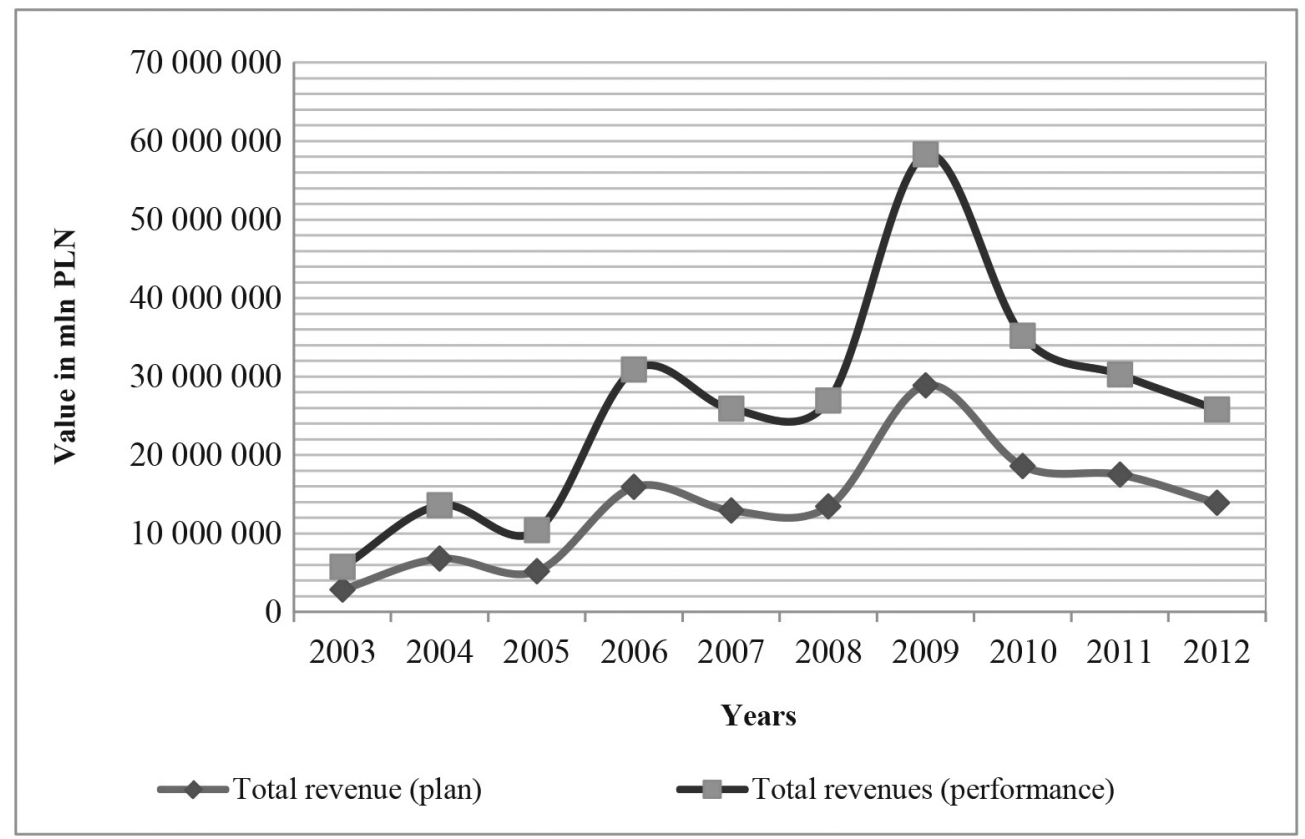

Fig. 3. The analysis of the implementation plan to the implementation performance of the revenues 2003-2012

The source: own elaboration.

Finally, the author made an analysis of the implementation plan to the implementation performance of the revenues 2003-2012, which the reader can see in 
the above graph (Fig. 3). In 2003 the revenues were very low, in the following year they were higher than before. Later, because of stopping the issuance of bonds they were again low and since 2006 they have started to increase. In 2009 the analysis showed how they were created and there is quite a big gap between them, caused by the actions taken by the government. Since 2010 they have become much more closer and the gap not so high as was noticed in 2009.

\section{Conclusion}

Municipal bonds are an important part of the financial instruments which they belong to. Even more important is the desire and decision of the authority of local governments to issue, as well as for running calculations, and at the same for research. Currently, municipal bond issues in the municipalities have been introduced by several local governments and are very popular, still successful in the market and every year continuing the issue. The issue of bonds allows the authorities to invest in other investments, such as other securities or properties. Thanks to this, the local population may also be gratified with building, renovation of premises or places of public use such as schools, repairs, construction of sports fields, road repairs or street lighting.

The paper turned attention to the concept of what an investment and a financial investment are. There was an explanation of the concept of municipal bonds, as well as the criteria for classification and the pricing of bonds, and introduced the initiation of the bond issue and further development of the issue. Subsequently the author focused on the sources of financing investment and based the research on the analysis of the important role of income and expenses for holding securities using the example of the Municipality Ostrów Wielkopolski. Through these qualities, which are not yet in any local government units, the essence of the securities in the community is very important. All this has given the author a positive outlook for further research in the field of financial investment. It was important to develop the same analysis because of the opportunity to learn the value of bonds in a budget.

The publication should be modified due to changing legislation, the information developed by the researchers, brokers, banks, corporations and guides. All of them are being published in ever greater number, especially the importance of working with the Financial Supervision and Regional Chambers of Accounting. It is important to obtain information on a regular basis, because in the context of changing laws and policies such as bonds (municipal bonds) a local government cannot take action without having basic rights.

The popularity of European Union funds and the experience of using them has overshadowed municipal bonds. Municipal bonds are generally the safest financial instrument, which results from the nature of the issuer - the local government. Their profitability is higher than treasury bonds. 


\section{Literature}

A Guide to the Project Management Body of Knowledge, 2000, PMBOK Guide.

Brochocka U., Gajęcki R., 1997, Metody oceny projektów inwestycyjnych, SGH, Warszawa.

Czapla W., 1996, Obligacje komunalne i mieszkaniowe, Fundacja Rozwoju Rachunkowości w Polsce, Warszawa.

Czechowska D., 2010, Instrumenty dlużne w gospodarce, Wydawnictwa Fachowe CeDeWu, Warszawa.

Dziworska K., Dziworski A., 1998, Podstawy matematyki finansowej, wyd. 2, Uniwersytet Gdański, Gdańsk.

Hirshleifer J., 1965, Investment decision under uncertainty: choice - theoretic approaches, Quarterly Journal of Economics 79.

Jajuga K., Jajuga T., 2004, Inwestycje. Instrumenty finansowe. Ryzyko finansowe. Inżynieria finansowa, Wydawnictwo Naukowe PWN, Warszawa.

Jajuga K., Jajuga T., 2007, Inwestycje. Instrumenty finansowe. Aktywa niefinansowe. Ryzyko finansowe. Inżynieria finansowa, Wydawnictwo Naukowe PWN, Warszawa.

Kamerschen D.R., McKenzie R.B., Nardinelli C., 1991, Ekonomia, Fundacja Gospodarcza NSZZ „Solidarność", Gdańsk.

Kompendium wiedzy o zarządzaniu projektami, 2003, MT\&DC, Warszawa.

Marcinek K., 2006, Finansowanie projektów inwestycyjnych na zasadach Project Finance, Prace Naukowe Akademii Ekonomicznej im. Karola Adamieckiego w Katowicach, Katowice.

Merkle J.A., 1980, Management and Ideology: The Legacy of the International Scientific Management Movement, University of California Press, California.

Ostrowski J., Stępniewski M., Śliwiński P., 2005, Obligacje komunalne i ich rola w finansowaniu inwestycji, Twigger, Warszawa.

Różański J., 2006, Inwestycje rzeczowe i kapitałowe, Centrum Doradztwa i Informacji, Difin, Warszawa. Trocki M., Grucza B., Ogonek K., 2003, Zarządzanie projektami, PWE, Warszawa.

MISTiA 2004, MISTiA na Szlaku, nr 1(3).

\section{Electronic Sources}

1. http://samorzad.infor.pl/sektor/finanse/rachunkowosc_budzetowa/artykuly/388541,zrodla_inwestycji_w_jednostkach_budzetowych.html, dated on 07.05.2014.

2. http://www.bgz.pl/downloads/biuro_maklerskie/Edukacja/Obligacje.pdf, KNF, dated on 07.05. 2014.

3. http://www.finanse.egospodarka.pl/36756,Obligacje-komunalne-czy-warto,1,48,1.html, dated on 07.05.2014.

4. http://www.knf.gov.pl/Images/Wprowadzenie\%20do\%20inwestycji\%20finansowych_tcm 75-17592.pdf, dated on 07.05.2014.

5. http://www.ostrow-wielkopolski.um.gov.pl, dated on 07.05.2014.

6. http://www.pwc.pl/pl/publikacje/wyzwania-inwestycyjne-miast/finansowanie-inwestycji.jhtml, dated on 07.05.2014. 